\author{
• ернявський ${ }^{1}$, . еліш ${ }^{2}$ \\ 1 ціон льний лісотехнічний університет кр їни, \\ вул. . обилянської, 1, м. ьвів, 79005, кр їн \\ 2 ввівський н ціон льний університет імені в н \\ вул. . орошенк , 41, м. ьвів, 79000, кр їн
}

бгрунтов но систему з ходів, спрямов них н реконструкцію похідних лісів у ерхньодністерських ескид х. меж х висотних рослинних смуг і висотних л ндш фтних місцевостей з пропонов но п р метри цільових деревост нів, з ходи з н ближеного до природного лісівництв т рекомендов ні способи рубок.

лючові слов : ерхньодністерські ескиди, висотні рослинні смуги, ліси, способи рубок, цільові деревост ни.

еред відновних природних ресурсів ерхньодністерських ескидів н йбільших змін з зн ли ліси, які не лише м ють для суспільств в гоме економічне й соці льне зн чення, й виконують грунтоз хисну, водорегулюв льну т інші природоохоронні функції. еб ж ні зміни в лісових екосистем х відбув лися у трьох н прям х: зменшення вкритої лісом площі, з мін міш них лісів монокультур ми смереки, сосни звич йної тощо, спрощення вікової й ценотичної структури, отже, зниження біологічної стійкості, продуктивності т з хисних вл стивостей лісів $[6,17]$.

лісових л ндш фт х регіону, де ліси є головним регулятором стоку в б сейні ністр , лісистість зменшил ся з 90-95\% [6] у до грокультурний період до 30-45\% сьогодні, що нег тивно вплинуло н гідрологічний режим. ут є пон д 10 тис. г смерекових монокультур т інших похідних деревост нів, які порівняно з корінними ліс ми м ють нижчу продуктивність і біологічну ст більність. х м сово пошкоджують шкідники т хвороби; водорегулюв льн й грунтоз хисн функція т ких лісів знижен [13]. тр нсформов них лісових л ндш фт х поч стіш ли небезпечні фізико-геогр фічні процеси.

ому необхідною є реконструкція тр нсформов них деревост нів з метою н ближення їхнього скл ду до природних лісів т оптиміз ція їхнього використ ння. ких з ходів треб вжив ти одноч сно зі збільшенням лісистості т підвищенням з хисних вл стивостей лісів. е є одним із головних з вд нь, що входять у комплексну проблему відтворення екологічного б л нсу гірських територій. ндш фтною й екологічною основою для вирішення цього з вд ння повинно ст ти н ближене до природного лісівництво - систем лісового господ рств , як зд тн з безпечити збереження лісового середовищ, відновний потенці л лісових екосистем т їхню б г тофункціон льну

() ернявський ., еліш ., 2012 
роль, т кож невисн жливе використ ння лісосировинних ресурсів з ур хув нням потреб суч сного т м йбутнього поколінь суспільств $[15,17,18]$.

т н лісів т проблеми лісового господ рств досліджув ного регіону висвітлені в публік ціях [6, 10-13], у яких з зн чено, що поліпшення ст ну н с джень можн досягнути лише в р зі впров дження системи лісівничо-технологічних з ходів, як передб ч $є$ т ке: перехід н вибіркову систему ведення лісового господ рств , вжиття 3 ходів з поліпшення с ніт рного ст ну деревост нів, з реконструкції смерекових молодняків, створення попередніх лісових культур і використ ння природних сукцесій у відновленні лісів. омплекс диференційов них з ходів для поліпшення скл ду і структури лісів ст новить систему н ближеного до природи лісівництв, як $\epsilon$ пр обр зом ведення лісового господ рств з зр зком природних лісів $[10,15,17]$.

етодологія н ближеного до природи лісівництв передб ч $є$ передусім моделюв ння природних процесів, відт к ужиття т кої системи з ходів, як посилює стійкість деревост нів і їхню б г тофункціон льну роль 3 мінім льно доцільного і необхідного втруч ння в ліс [17]. етодичні з с ди досліджень структури і дин міки лісів грунтуються н типологічній основі [3] і біометрії дерев з переліковою їх т кс цією [1], вивченням процесів природного поновлення і розвитку деревост нів н популяційних з с д х. ля н лізу ст ну деревост нів використовув ли уніфіков ні пок зники просторової орг ніз ції фітоценозів [14].

ля прогнозув ння розвитку н с джень і їхньої кл сифік ції з стосовув ли системний підхід [2] з п р метр ми, що з пропонов ні для цього цюріхськими лісівник ми [18] й уточнені н ми $[8,16,17]$.

ш мет - н ліз т оцінк суч сного ст ну лісів ерхньодністерських ескидів 3 лісівничих [8] і конструктивно-геогр фічних позицій [11], обгрунтув ння системи 3 ходів, спрямов них н збереження, відтворення т р ціон льне використ ння лісів [9].

ослідження проведено в природних і штучних деревост н х типових л ндш фтів ерхньодністерських ескидів н 26 ст ціон рних і тимч сових ділянк х перев жних типів лісу регіону. підст ві опр цюв ння м тері лів лісовпорядкув ння т вивчення природних лісів скл дено типи цільових деревост нів з лежно від типу лісу.

ерхньодністерські ескиди - с стин хідних ескидів у меж х ьвівської обл. північному сході обмежені ередк рп ттям, н південному сході - колівськими ескид ми, н південному з ході - трийсько- янською ерховиною. нутрішнюч стину ерхньодністерських ескидів 3 мик є хребет гури імнянської, бо озлуцький. ершин гур імнянськ (1 021 м) є н йвищою в р йоні. ересічн висот - близько 750 м [4]. ерев ж є низькогірний рельєф з куполоподібними вершин ми хребтів, що розчленовують притоки ністр, тривігору, трию т інших річок. ори вкриті хвойно-широколистяними ліс ми. вдяки “дощовій тіні” у верхів'ї б сейну ністр існують сприятливі екологічні умови для росту ялиці, як формує зміш ні з буком, смерекою, іноді й чисті деревост ни. ей регіон порівняно з іншими ч стин ми рп т густон селений, з розвиненим землеробством.

ндш фти ерхньодністерських ескидів 3 йм ють північно-з хідну ч стину кибових рп т із висот ми 350-1 022 м н. р. м. площею $1311,6 \mathrm{~km}^{2}$. ля них х р ктерний низькогірний рельєф із м'якими обрис ми. регіоні протягом року вип д $є 700$ 800 мм оп дів, середньорічн темпер тур повітря - 6,6-8,3 $3^{\circ}$. ут поширені родючі бурі гірсько-лісові грунти різної потужності. регіоні дослідження виділено дв індивіду льні л ндш фти: рівський $\left(486 \mathrm{~km}^{2}\right)$ т ерхньодністерський $\left(825,6 \mathrm{kM}^{2}\right)$, у меж х 
яких н лічують п’ять висотних місцевостей, із яких н йбільші площі з йм ють низькогірні широкі міжскибові зниження т сп дисто- і крутосхилі розчленов ні хребти [7].

кологічні умови регіону сприятливі для вирощув ння стійких і високопродуктивних листяних т хвойних лісів. гідно з геобот нічним р йонув нням кр їнських

рп т . олубця [5], ерхньодністерські ескиди - це перев жно округ букових к рп тських лісів. ертик льн диференці ція рослинного покриву є природним н слідком екологічної відповідності рослинних форм цій як темпер турним, т к і усім ін. екологічним чинник м, які змінюються не лише з висотою н д рівнем моря, й 3 лежно від положення т н пряму гірських хребтів, х р ктеру долин гірських річок i, вз г лі, з лежно від геоморфологічної структури місцевості. ерхньодністерських ескид $\mathrm{x}$. тойко виділив висотні рослинні смуги: дубових лісів з дуб звич йного; ялицево-дубових лісів з дуб звич йного; букових лісів; ялицево-букових і буковоялицевих лісів [10].

и провели фізико-геогр фічні й лісівничі дослідження т виявили осередки природних лісів $[8,11,12]$ у меж х чотирьох висотних рослинних смуг ( ), які приурочені до різних природно-територі льних комплексів з 18 тип ми лісу (т бл. 1).

блиця 1

исотні рослинні смуги у ерхньодністерських ескид х

\begin{tabular}{|c|c|c|c|}
\hline $\begin{array}{l}\text { исотні рослинні } \\
\text { смуги }\end{array}$ & $\begin{array}{l}\text { риродно- } \\
\text { територі льний } \\
\text { комплекс }\end{array}$ & $\begin{array}{l}\text { ередні } \\
\text { висоти, } \\
\text { м н.р.м. }\end{array}$ & ипи лісу т їхня площ , г \\
\hline $\begin{array}{l}\text { убові ліси з дуб } \\
\text { звич йного } \\
\text { (Quercetum roboris) }\end{array}$ & $\begin{array}{l}\text { изькогірні міжскибові } \\
\text { зниження т долини } \\
\text { головних рік рівського } \\
\text { л ндш фту }\end{array}$ & $250-350$ & $\begin{array}{l}\text { олог гр бов судібров - } \\
1379,5 ; \text { свіж гр бов дібров - } \\
164 ; \text { волог гр бов дібров - } \\
1503,3\end{array}$ \\
\hline $\begin{array}{l}\text { лицево-дубові } \\
\text { ліси з дуб } \\
\text { звич йного (Abieto- } \\
\text { Quercetum roboris) } \\
\text { (диз'юнктивний) }\end{array}$ & $\begin{array}{l}\text { изькогірні міжскибові } \\
\text { зниження рівського т } \\
\text { ерхньодністерського } \\
\text { л ндш фтів }\end{array}$ & $350-450$ & $\begin{array}{l}\text { олог ялицев судібров - } \\
631,7 \text {; волог ялицев дібров - } \\
933,8 \text {; волог дубов яличин - } \\
475,5 ; \text { волог дубов суяличин } \\
-782,6\end{array}$ \\
\hline $\begin{array}{l}\text { укові ліси } \\
\text { (Fagetum } \\
\text { sylvaticae) }\end{array}$ & $\begin{array}{l}\text { изькогірні міжскибові } \\
\text { зниження, низькогірні } \\
\text { т середньогірні } \\
\text { розчленов ні хребти } \\
\text { ерхньодністерського } \\
\text { л ндш фту }\end{array}$ & $450-1020$ & $\begin{array}{l}\text { олог чист субучин }-42,0 ; \\
\text { волог гр бово-дубов } \\
\text { субучин }-10,6 \text {; волог гр бов } \\
\text { субучин }-51,5 \text {; свіж гр бово- } \\
\text { дубов бучин }-3,9 ; \text { волог } \\
\text { гр бово-дубов бучин - } \\
391,2 \text {; волог гр бов бучин - } \\
24,3\end{array}$ \\
\hline $\begin{array}{l}\text { лицево-букові т } \\
\text { буково-ялицеві } \\
\text { ліси (Abieto- } \\
\text { Fagetum et Fageto- } \\
\text { Abietum) }\end{array}$ & $\begin{array}{l}\text { изькогірні міжскибові } \\
\text { зниження, низькогірні } \\
\text { т середньогірні } \\
\text { розчленов ні хребти } \\
\text { ерхньодністерського } \\
\text { л ндш фту }\end{array}$ & $500-0,800$ & $\begin{array}{l}\text { віж смереково-буков } \\
\text { суяличин - } 3232,9 ; \text { волог } \\
\text { буков суяличин -9287,4; } \\
\text { волог ялицев субучин - } \\
1333,3 \text {; } \\
\text { волог буково-смереков } \\
\text { суяличин - } 16498 \text {; волог } \\
\text { гр бово-буков яличин - } \\
5815,0\end{array}$ \\
\hline
\end{tabular}


иділені слугують екологічною основою для ведення лісового господ рств 3 зр зком природних екосистем т цілеспрямов ної реконструкції м лоцінних похідних деревост нів. ля пл нув ння лісогоспод рських з ходів, спрямов них н підтримку якісної структури, м ксим льно можливої продуктивності і ст більної біотичної різном нітності, необхідно зн ти х р ктеристики корінних і змінених природними чинник ми і дією людини деревост нів $[8,18]$.

лісових л ндш фт х ерхньодністерських ескидів дубові ліси були поширені у меж х висот 250-350 м н.р.м. ередньорічн темпер тур - 7-8 ${ }^{\circ}$, кількість оп дів 550-600 мм. еріод вегет ції ст новить близько 210 днів. долин х рік поширені дерново-підзолисті глейові, н підвищеннях і межиріччях - сірі опідзолені грунти. меж х поясу н йпоширеніші висотні місцевості низькогірних міжскибових знижень т долин головних рік. ля дубових лісів х р ктерн досить велик різном нітність типів лісу. Знижених елемент х рельєфу це сир ясенев з пл вн дібров, сир гр бов дібров , сир гр бов судібров , у підвищених місцевостях-свіж і волог гр бов судібров , свіж і волог гр бов дібров . оловні пок зники цільових лісів дубових лісів н ведено в т бл. 2.

оловні пок зники суч сних і цільових деревост нів у

блиця 2

дубових лісів

\begin{tabular}{|c|c|c|}
\hline ок зники & труктур суч сних деревост нів & $\begin{array}{l}\text { труктур цільових } \\
\text { деревост нів }\end{array}$ \\
\hline \multicolumn{3}{|c|}{ ісцевості низькогірних міжскибових знижень т долини головних рік рівського л ндш фту } \\
\hline оходження & $\begin{array}{l}\text { риродних дубових деревост нів м йже } \\
\text { нем , н с дження пройдені інтенсивними } \\
\text { рубк ми. ерев ж ють культури дуб бо } \\
\text { деревост ни міш ного походження (дуб - } \\
\text { у культур х, гр б, бук і ясен природного } \\
\text { порослевого і н сіннєвого походження, } \\
\text { ін. породи - перев жно природного по- } \\
\text { ходження) }\end{array}$ & $\begin{array}{l}\text { іш ні з скл дом і скл дні з } \\
\text { структурою деревост ни пере- } \\
\text { в жно природного і природно- } \\
\text { штучного походження з пере- } \\
\text { в ж нням у скл ді дуб зви- } \\
\text { ч йного, головних (ясен) і су- } \\
\text { путніх (гр б, в’яз, берест, лип } \\
\text { серцелист, черешня) порід } \\
\text { н сіннєвого походження }\end{array}$ \\
\hline \multirow{3}{*}{$\begin{array}{l}\text { кл д } 3 \text { лежно } \\
\text { від типів лісу }\end{array}$} & \begin{tabular}{|cccccc}
10 & зВ+ & с од. & К & в & К \\
ХЧ \\
\end{tabular} & 9 зв1 \\
\hline & 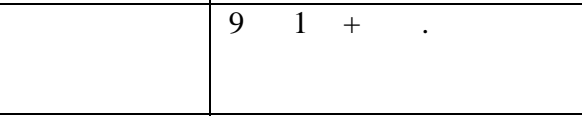 & 6-7 зв1-2 $\mathrm{cl}+$ п л 3 к. \\
\hline & $\begin{array}{l}9 \text { зв } 1+\text { к од. } \quad \text { с } \\
\text { к П }\end{array}$ & $\begin{array}{ccccccc}8-9 & \text { зв } 1-2 & \mathrm{c}+ & \text { к } & \text { в } & \text { од. } & \text { П } \\
\text { рш } & \text { Хч } & & & & & \end{array}$ \\
\hline $\begin{array}{c}\text { іков } \\
\text { структур } \\
\end{array}$ & $\begin{array}{l}\text { ерев жно одновіков і подекуди умовно- } \\
\text { різновіков }\end{array}$ & $\begin{array}{l}\text { ерев жно різновіков } \\
\text { умовно-різновіков }\end{array}$ \\
\hline $\begin{array}{l}\text { ертик льн } \\
\text { структур }\end{array}$ & ерев жно одно- і двоярусн & $\begin{array}{l}\text { ерев жно двоярусн і } \\
\text { триярусн }\end{array}$ \\
\hline $\begin{array}{l}\text { оризонт льн } \\
\text { структур }\end{array}$ & $\begin{array}{l}\text { ерев жно біогрупове і нерівномірне } \\
\text { розміщення порід у природних дерево- } \\
\text { ст н х, близьке до рівномірного серед де- } \\
\text { рев першого ярусу - у культур х }\end{array}$ & $\begin{array}{l}\text { ерев жно біогрупове розмі- } \\
\text { щення головних порід }\end{array}$ \\
\hline
\end{tabular}


оловною метою н ближеного до природи лісівництв в меж $\mathrm{x}$ дубових лісів $\epsilon$ досягнення м ксим льного стимулюв ння н сіннєвого поновлення дуб звич йного і з ходи сприяння його росту й розвитку, переформув ння дібров порослевого походження в н сіннєві, створення міш них $з$ скл дом і скл дних з структурою н с джень природного і штучного походження, відбір і селекція форм і популяцій дуб, які н йстійкіші до клім тичних умов і з хворюв нь. ріоритетним є формув ння ценотичної т вікової структури в дібровному ценотичному комплексі з зр зком екологічно ст більних природних лісів; збереження біологічного т фітоценотичного різном ніття як природної сп дщини, що з безпечує екологічну ст більність екосистем, як виникл протягом філоценогенетичного процесу $[8,10]$.

е ст не передумовою доброї збереженості, стійкості т довговічності дубових лісів. ля досягнення цієї мети необхідно вжити з ходи з н ближеного до природи лісівництв (див. т бл. 6).

исотний пояс ялицево-дубових лісів з дуб звич йного (Abieto-Quercetum roboris) розт шов ний вузькою смугою у ередк рп тті т низькогірних висотних місцевостях обох л ндш фтів ерхньодністерських ескидів. ередні висоти поясу - 350-450 м н. p. м. ін сформув вся в умов х помірно теплого клім ту з сумою ктивних темпер тур 2 200-2 $600^{\circ}$. ередньорічн темпер тур $-7-8^{\circ}$, кількість оп дів - 600-700 мм. е-рев жниими висотними місцевостями є низькогірні широкі міжскибові зниження. меж х поясу н йпоширеніші т кі типи лісу: волог ялицев дібров , сир ялицев судібров , волог дубов яличин , волог дубов суяличин . оловні пок зники ялицеводубових лісів н ведено в т бл. 3.

блиця 3

оловні пок зники суч сних і цільових деревост нів у ялицево-дубових лісів

\begin{tabular}{|c|c|c|}
\hline ОК ЗНИКИ & труктур суч сних деревост нів & $\begin{array}{l}\text { труктур цільових } \\
\text { деревост нів }\end{array}$ \\
\hline \multicolumn{3}{|c|}{$\begin{array}{r}\text { ісцевості низькогірних міжскибових знижень } \\
\text { л ндшського т } \quad \text { ерхів }\end{array}$} \\
\hline 1 & 2 & 3 \\
\hline оходження & $\begin{array}{l}\text { риродних деревост нів м ло, н с дження } \\
\text { пройдені інтенсивними руб ннями. ерев - } \\
\text { ж ють культури дуб бо деревост ни міш - } \\
\text { ного походження (дуб - культури, ялиця } \\
\text { природного походження). }\end{array}$ & $\begin{array}{l}\text { іш ні з скл дом і скл дні } \\
3 \text { структурою ялицево-ду- } \\
\text { бові н с дження перев жно } \\
\text { природного і природно-штуч- } \\
\text { ного походження }\end{array}$ \\
\hline \multirow{4}{*}{$\begin{array}{c}\text { кл д } \\
3 \text { лежно від } \\
\text { типу лісу }\end{array}$} & $\begin{array}{l}\text { олог ялицев } \\
\text { судібровв }\end{array}$ & 6-7 $33-4$ ц+ м \\
\hline & $\begin{array}{l}\text { олог ялицев } \\
\text { дібров }\end{array}$ & $\begin{array}{l}7-8 \text { зв } 2-3 \\
\text { Хч }\end{array}$ \\
\hline & $\begin{array}{l}\text { олог дубов } \\
\text { яличин }\end{array}$ & $\begin{array}{l}\text { 6-8 ц2-3 м1-2 к+ од. В } \\
\text { с }\end{array}$ \\
\hline & $\begin{array}{l}\text { олог дубов } \\
\text { суяличин }\end{array}$ & 6-8 ц1-2 к од. в \\
\hline $\begin{array}{c}\text { іков } \\
\text { структур } \\
\end{array}$ & дновіков й умовно-різновіков & $\begin{array}{l}\text { ерев жно різновіков } \\
\text { умовно-різновіков }\end{array}$ \\
\hline $\begin{array}{l}\text { ертик льн } \\
\text { структур }\end{array}$ & $\begin{array}{l}\text { ерший ярус формує дуб, до якого місцями } \\
\text { доміш ні супутні породи. ругий ярус утво- } \\
\text { рють ялиця, зрідк бук, лип серцелист . } \\
\text { рус підліску з ліщини, горобини, крушини } \\
\text { сформов ний у лісост н х, де головну еди- } \\
\text { фік торну роль відігр є дуб. }\end{array}$ & ерев жно дво- і триярусн \\
\hline
\end{tabular}




\begin{tabular}{|c|l|c|}
\multicolumn{1}{|c|}{ кінчення $m$ бл. 3} \\
\hline 1 & \multicolumn{1}{|c|}{2} & \multicolumn{1}{|c|}{3} \\
\hline $\begin{array}{c}\text { оризонт ль } \\
\text { н } \\
\text { структур }\end{array}$ & $\begin{array}{l}\text { ерев жно біогрупове і нерівномірне розмі- } \\
\text { близьке до рівномірного серед дерев першо- } \\
\text { го ярусу - у культур х }\end{array}$ & міщення головних порід \\
\end{tabular}

поясі ялицево-дубових т дубово-ялицевих лісів головною метою н ближеного до природи лісівництв $\epsilon$ досягнення стимулюв ння появи підросту н сіннєвого походження, сприяння його розвитку й росту, створення міш них з скл дом і скл дних 3 структурою ялицево-дубових і дубово-ялицевих лісів природного і штучного походження.

исотн смуг букових лісів (Fagetum sylvaticae) з йм є у ерхньодністерських ескид х зн чну площу. учини є н йх р ктернішою форм цією для всіх хідних ескидів, з г льн їхня площ в меж х ерхньодністерського т рівського л ндш фтів ст новить пон д 5 тис. г. они поширені в усіх лісництв х “т рос мбірське

” т т рос мбірського “ лсільліс" у меж х висот 450-1 020 м н. р. м. у помірній (сум ктивних темпер тур $1800-2400^{\circ}$ ) клім тичній зоні. ередньорічн темпер тур $-7-8^{\circ}$, кількість оп дів - 600-1 000 мм.

меж х вегет ційного ступеня перев ж ють бурі гірсько-лісові грунти. йбільшу площу з йм ють місцевості низькогірних міжскибових знижень, низько- т середньогірних розчленов них хребтів. ля х р ктерн велик різном нітність типів лісу: свіж гр бово-дубов субучин й бучин, волог гр бов субучин й бучин, сир бучин, волог гр бово-ялицев субучин й бучин, волог чист субучин й бучин, свіжий і вологий чисто буковий субір. оловні пок зники букових деревост нів н ведено в т бл. 4.

оловною метою н ближеного до природи лісівництв у букових лісів $є$ формув ння високопродуктивних і скл дних з структурою н с джень, підтрим ння їхньго високого природного відновлюв ного потенці лу, перетворення лісогоспод рськими з ход ми низькостовбурних зріджених деревост нів у високостовбурні й високоповнотні, р ціон льне використ ння цінного генофонду порід постійної лісон сіннєвої б зи, своєч сне вжиття с ніт рно-оздоровчих з ходів т рубок догляду з лісом [8, 18]. ля досягнення цієї мети необхідно у букових лісів ужити з ходів з н ближеного до природи лісівництв (див. т бл. 6).

исотн рослинн смуг ялицево-букових т буково-ялицевих лісів (Abieto-Fagetum et Fageto-Abietum) сформов н у меж х висот 700-900 м н. р. м. вдяки сприятливим грунтово-клім тичним умов м і н явності “дощової тіні” тут є досить сприятливі екологічні умови для формув ння зміш них ялицево-букових лісост нів. минулому т ких лісів у регіоні було зн чно більше, проте корінні ялицево-букові ліси були тр нсформов ні в смеречники. міш ні ялицево-букові ліси приурочені здебільшого до тіньових північних, північно-східних т південно-з хідних схилів і вузьких з тінених ущелин.

площею перев ж ють низькогірні міжскибові зниження, низько- т середньогірні розчленов ні хребти. меж х поясу домінують свіжі і вологі букові яличини й суяличини. оловні цільові пок зники буково-ялицевих і ялицево-букових лісів н ведені в т бл. 5.

оловною метою н ближеного до природи лісівництв у буково-ялицевих й ялицево-букових лісів є відтворення різновікового міш ного деревост ну, з безпечення н сінневого поновлення ялицево-букових лісів, відновлення їхньої просторової т ви- 
дової різном нітності. е буде передумовою доброї збереженості, стійкості т довговічності цих лісів. ля досягнення цієї мети необхідно переходити н систему н ближеного до природного лісівництв (т бл. 6).

оловні пок зники суч сних і цільових деревост нів у

блиця 4

букових лісів

\begin{tabular}{|c|c|c|c|}
\hline ОК зники & \multicolumn{2}{|c|}{ труктур суч сних деревост нів } & труктур цільових деревост нів \\
\hline \multicolumn{4}{|c|}{$\begin{array}{c}\text { ісцевості низькогірних міжскибових знижень, низькогірних і середньогірних хребтів } \\
\text { ерхньодністерського л ндш фту }\end{array}$} \\
\hline оходження & \multicolumn{2}{|c|}{$\begin{array}{l}\text { скл ді деревост нів букових лісів } \\
\text { беруть уч сть пр ктично всі боригенні } \\
\text { породи: гр б, ялиця, явір, смерек , ясен } \\
\text { звич йний, в'яз гірський, черешня }\end{array}$} & $\begin{array}{l}\text { еобхідно зберегти з лишки пр - } \\
\text { лісів, як ет лони структури при- } \\
\text { родних лісів. північних схил х } \\
\text { перев гу відд в ти у домішці } \\
\text { хвойним, н південних - листя- } \\
\text { ним пород м }\end{array}$ \\
\hline \multirow{6}{*}{$\begin{array}{c}\text { кл д } \\
\text { з лежно від } \\
\text { типу лісу }\end{array}$} & $\begin{array}{l}\text { олог чист } \\
\text { субучин }\end{array}$ & 7 к3 зв од. к м & 7-8 $\quad$ к1-2 з+ с с ц \\
\hline & $\begin{aligned} & \text { олог } \text { гр бово- } \\
& \text { дубов } \text { субучин } \\
&\end{aligned}$ & $\begin{array}{ccccc}8 & \text { к1 } & 31 & \text { м+ од. } \\
& \text { ц } & \text { д } & \\
\end{array}$ & 6-7 $\quad$ к3 3 зв1 \\
\hline & $\begin{array}{l}\text { олог гр бов } \\
\text { субучин }\end{array}$ & $\begin{array}{cccccc}8 & \text { к1 } & \text { зв } 1 & \text { М+ } & \text { од. } \\
& \text { ц } & \text { д } & \text { ч } & \text { с } & \text { в }\end{array}$ & $\begin{array}{clllllll}6-7 & \text { к1-2 } & \text { зв1 } & \text { с1 } & \text { в } & \text { од. } & \text { Хч } & \text { П } \\
\text { Л } & \text { Ц } & & & & & & \\
\end{array}$ \\
\hline & $\begin{array}{l}\text { віж гр бово- } \\
\text { дубов бучин }\end{array}$ & $\begin{array}{cccccc}7 & \text { к3 } & \text { зв+ } & \text { м } & \text { од. } & \text { Ц } \\
\text { д } & \text { ч } & \text { с } & \text { в } & \text { К } \\
\text { с } & & & & \\
\end{array}$ & 6-7 к2-3 зв1 + с в од. ц м \\
\hline & $\begin{aligned} & \text { олог } \text { гр бово- } \\
& \text { дубов } \text { бучин } \\
&\end{aligned}$ & $\begin{array}{cccccc}8 & \text { к1 } & 31 & \text { м } & \text { од. } \\
\text { д } & \text { с } & \text { В } & \text { К } & \\
\end{array}$ & $\begin{array}{l}\text { 7-8 к1-2 } 31+\text { с в } \\
\text { хч }\end{array}$ \\
\hline & $\begin{array}{r}\text { олог гр бов } \\
\text { бучин }\end{array}$ & $\begin{array}{ccccc}9 & \text { к1 } & \text { м+ } & \text { од. } & \text { Ц } \\
\text { д } & \text { ч } & \text { с } & \text { к } & \\
\end{array}$ & $\begin{array}{ccccccc}7-8 & \text { к1-2 } 31+\mathrm{c} & \text { в } \text { Зв од. } \\
\text { П } & \text { Л } & & & \\
\end{array}$ \\
\hline $\begin{array}{l}\text { іков } \\
\text { структур }\end{array}$ & \multicolumn{2}{|c|}{$\begin{array}{l}\text { тучні н с дження перев жно умовно- } \\
\text { одновікові, гр бові бучини і субучини - } \\
\text { умовно-різновікові }\end{array}$} & $\begin{array}{l}\text { ерев жно різновіков у гр бових } \\
\text { бучин х і субучин х }\end{array}$ \\
\hline $\begin{array}{l}\text { ертик льн } \\
\text { структур }\end{array}$ & \multicolumn{2}{|c|}{$\begin{array}{l}\text { тучні н с дження перев жно одно-, } \\
\text { двоярусні, гр бові бучини - двоярусні }\end{array}$} & $\begin{array}{l}\text { ерев жно двоярусн у гр бових } \\
\text { бучин х і субучин х } \\
\end{array}$ \\
\hline $\begin{array}{l}\text { оризон- } \\
\text { т льн } \\
\text { структур }\end{array}$ & \multicolumn{2}{|c|}{$\begin{array}{l}\text { ерев жно біогрупове i нерівномірне } \\
\text { розміщення порід у природних дерево- } \\
\text { ст н х, близьке до рівномірного у дерев } \\
\text { першого ярусу - у культур х }\end{array}$} & $\begin{array}{l}\text { ерев жно рівномірне розміщен- } \\
\text { ня порід }\end{array}$ \\
\hline
\end{tabular}

тже, систем ведення лісового господ рств у ліс $\mathrm{x}$ ерхньодністерських ескидів повинн грунтув тися н 3 с д х лісівництв, н ближеного до природних лісів. истем н ближеного до природного лісівництв поляг є у формув нні т ких лісів, що з видовим скл дом порід, просторовою, ценотичною і віковою структурою близькі до природних лісів і пр лісів, у яких протягом філоценогенезу виробил ся зд тність до с морегулюв ння, біологічного с моз хисту, природного с мовідновлення, що з безпечує в їхньому циклі розвитку норм льне функціонув ння т гомеост 3 . истему ст лого лісового господ рств треб з пров джув ти диференційов но, з лежно від типу лісу. дібров х деревост ни, н відміну від бучин, відрізняються скл днішою ценотичною структурою, полідомін нтністю, розімкнутим н метом ун слідок світловиб гливості дубів. вдяки т ким еколого-біологічним вл стивостям дубові ліси н леж ть 
до ценотично л більних, що треб м ти н ув зі в р зі оцінюв ння міжвидових вз ємовідношень у полідомін нтних фітоценоз х. ипи міш них дубових, букових, ялицевих деревост нів необхідно оцінюв ти комплексно, вр ховуючи скл д, структуру і стійкість деревост нів т природні відновні процеси в них. і п зон трив лості фз розвитку природного лісу і штучно створених н с джень неодн ковий.

блиця 5

оловні пок зники суч сних і цільових деревост нів у буково-ялицевих лісів

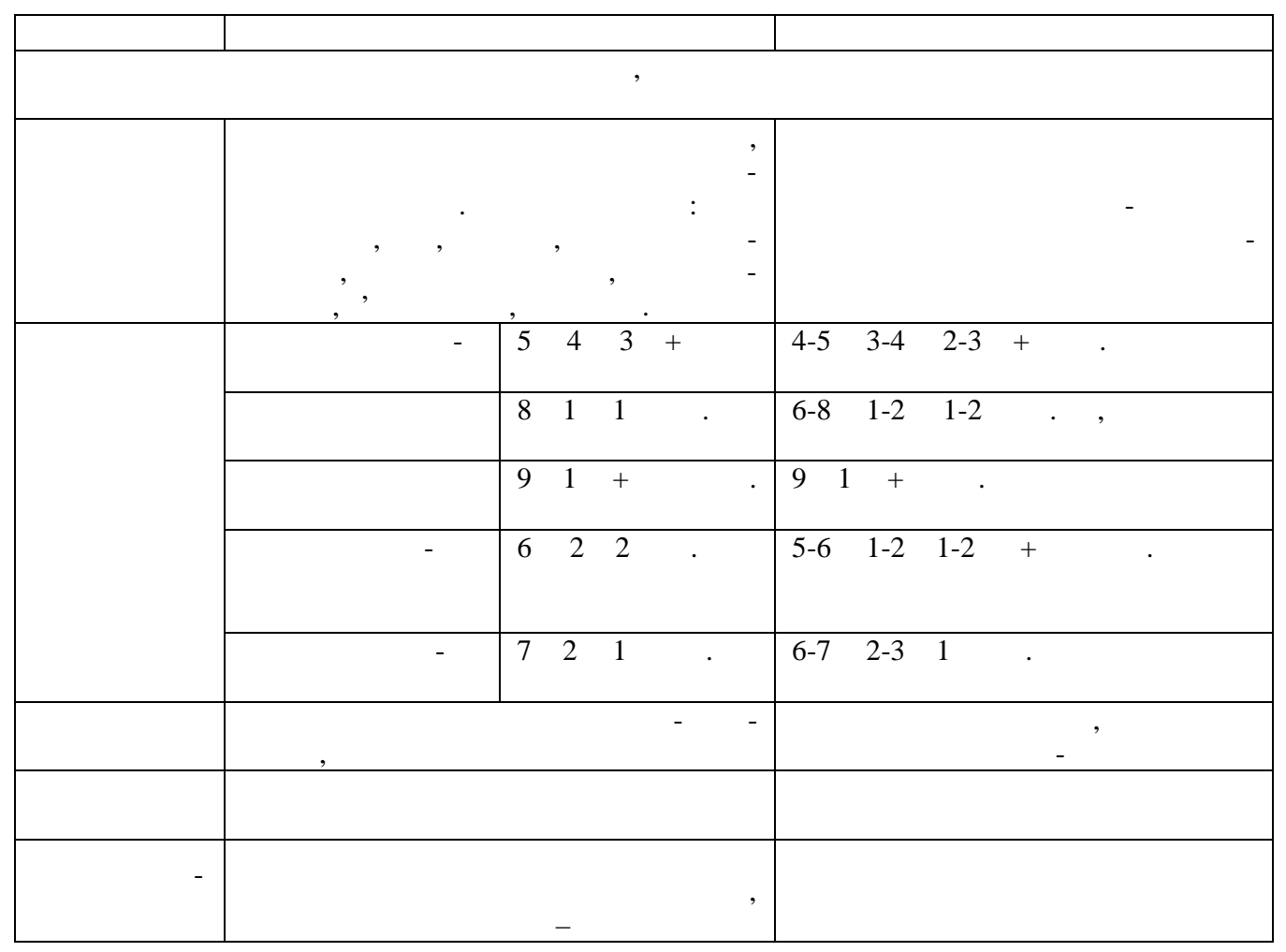

дним зі шляхів поліпшення структури лісів т оптиміз ції лісокористув ння у л ндш фт х ерхньодністерських ескидів є переформув ння смерекових монокультур т інших похідних лісів. кологічними з с д ми н ближеного до природного лісівництв треб керув тися т кож у р зі реконструкції гр бняків, смеречників т інших вторинних деревост нів, які виникли н місці корінних лісів. е д сть змогу поліпшити викон ння ліс ми регіону економічної, екологічної т соці льної функцій.

бгрунтов н в меж х л ндш фтів ерхньодністерських ескидів систем лісівництв 3 зр зком природних лісів регл ментує різнопл нові з ходи щодо природного поновлення, рубок догляду, головного користув ння і рубок переформув ння н с джень, збереження біотичного різном ніття, з хисту лісів, проведення реконструкції тр нсформов них н с джень т оптиміз ції лісовирощув ння. он охоплює для кож- 
блиця 6

истем 3 ходів 3 н ближеного до природного лісівництв в ліс $\mathbf{x}$ ерхньодністерських ескидів

\begin{tabular}{|c|c|c|c|c|}
\hline \multirow{2}{*}{$\begin{array}{c}\text { ходи } \\
\text { н ближеного } \\
\text { до } \\
\text { природного } \\
\text { лісівництв }\end{array}$} & \multicolumn{4}{|c|}{ исотні рослинні смуги } \\
\hline & $\begin{array}{c}\text { дубові ліси з дуб } \\
\text { звич йного } \\
\text { (Quercetum roboris) }\end{array}$ & $\begin{array}{l}\text { ялицево-дубові ліси з дуб } \\
\text { звич йного (Abieto-Quercetum } \\
\text { roboris) (диз’юнктивний) }\end{array}$ & $\begin{array}{c}\text { букові ліси } \\
\text { (Fagetum sylvaticae) }\end{array}$ & $\begin{array}{c}\text { ялицево-букові і буково- } \\
\text { ялицеві ліси (Abieto- } \\
\text { Fagetum et Fageto-Abietum) }\end{array}$ \\
\hline 1 & 2 & 3 & 4 & 5 \\
\hline $\begin{array}{l}\text { ідбір форм і } \\
\text { p c } \\
\text { (екотипів) } \\
\text { порід }\end{array}$ & $\begin{array}{l}\text { йліпшими клім тичними } \\
\text { екотип ми є південно-з хід- } \\
\text { ний і з хідний. оцільно } \\
\text { відтворюв ти н гірну і з п- } \\
\text { л вну популяцію дуб зви- } \\
\text { ч йного, вр ховув ти фено- } \\
\text { логічні різновидності. } \\
\text { верхніх ч стин х схилів тре- } \\
6 \text { відтворюв ти дуб р н- } \\
\text { ньої, в нижніх - пізньої } \\
\text { форми }\end{array}$ & $\begin{array}{l}\text { дубів н йприд тнішими є пів- } \\
\text { денно-з хідний і } з \text { хідний еко- } \\
\text { типи. еред ялиць - форм яли- } \\
\text { ці, що пізно розпуск ється. } \\
\text { свіжих тип х лісу перспективні } \\
\text { з сухостійкі форми. ерев гу } \\
\text { необхідно н д в ти швидкорос- } \\
\text { тучій формі ялиці. свіжих ти- } \\
\text { п х лісу перспективні } 3 \text { сухо- } \\
\text { стійкі форми }\end{array}$ & $\begin{array}{l}\text { ля бук х р ктерн ве- } \\
\text { лик кількість природно- } \\
\text { геогр фічних і ед фіч- } \\
\text { них форм, відбір яких } \\
\text { упродовж формув ння } \\
\text { деревост нів сприяє прис- } \\
\text { кореним процес м рос- } \\
\text { ту деревост нів }\end{array}$ & $\begin{array}{l}\text { ерев гу необхідно н д - } \\
\text { в ти швидкоростучій кону- } \\
\text { соподібній формі ялиці } 3 \\
\text { гостокутною формою. ід- } \\
\text { бир ти цільові дерев тре- } \\
\text { б } 3 \text { пр вильною формою } \\
\text { стовбур т очищув ти йо- } \\
\text { го нижні ч стини від гілок }\end{array}$ \\
\hline $\begin{array}{c}\text { прияння } \\
\text { природному } \\
\text { поновленню }\end{array}$ & $\begin{array}{l}\text { реб проводити шляхом } \\
\text { зменшення зімкнутості м - } \\
\text { теринського деревост ну, } \\
\text { вирубуючи підлісок смуг - } \\
\text { ми шириною 1-2 м, очищу- } \\
\text { в ти і розпушув ти ці смуги } \\
\text { культив тором, борон ми } \\
\text { т вручну у в жкодоступ- } \\
\text { них місцях з ущільненого } \\
\text { грунту, розгріб ти підстил- } \\
\text { ку }\end{array}$ & $\begin{array}{l}\text { йліпше проходить під н ме- } \\
\text { том лісу, хоч в рто зменшу- } \\
\text { в ти зімкнутість деревост ну, } \\
\text { спушув ти грунт. ступного } \\
\text { поновлення досяг ють, регулю- } \\
\text { ючи освітлення під н метом де- } \\
\text { ревост ну }\end{array}$ & 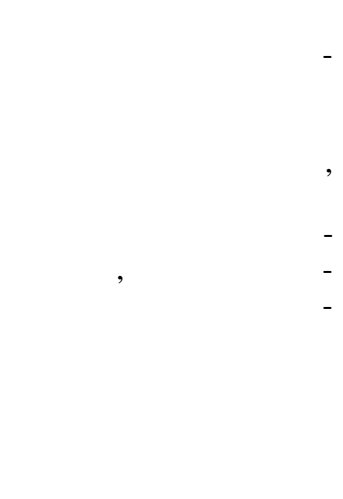 & $\begin{array}{l}\text { оновлення ялиці відбув - } \\
\text { ється успішно під н метом } \\
\text { лісу, життєзд тністю пон д } \\
100-120 \text { років. ідновлен- } \\
\text { ня н суцільних зруб х } \\
\text { менш успішне. ояві під- } \\
\text { росту сприяє збільшення } \\
\text { зімкнутості м теринського } \\
\text { деревост ну (оптим льно } \\
\text { до 0,6), розгріб ння під- } \\
\text { стилки і спушення грунту. } \\
\text { олоде покоління бук і } \\
\text { ялиці б ж но вирощув ти } \\
\text { під н метом дерев }\end{array}$ \\
\hline
\end{tabular}




\begin{tabular}{|c|c|c|c|c|}
\hline 1 & 2 & 3 & 4 & 5 \\
\hline $\begin{array}{c}\text { огляд } 3 \\
\text { підростом }\end{array}$ & 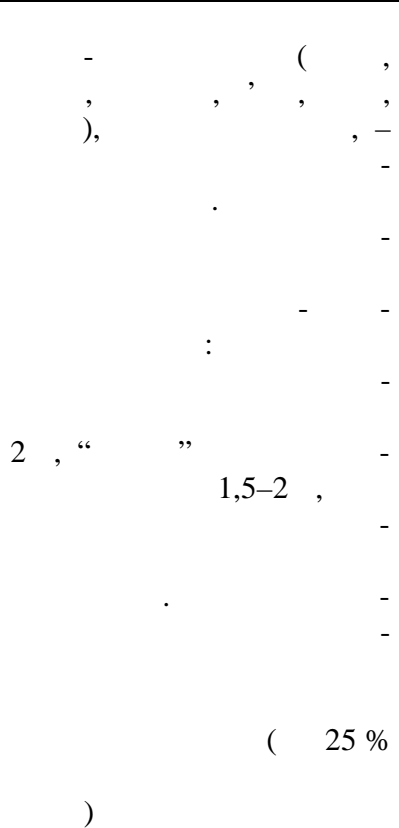 & $\begin{array}{l}\text { ідріст доцільно формув ти } \\
\text { густими концентричними кур- } \\
\text { тин ми. годом іх необхідно } \\
\text { переформув ти. рто збері- } \\
\text { г ти підріст порід-супутників } \\
\text { т з потреби проводити освіт- } \\
\text { лення. міш них чи неодно- } \\
\text { рідних з походженням молод- } \\
\text { няк х проводити смугово-ви- } \\
\text { бірковий догляд, щоб сформу- } \\
\text { в ти міш ні н с дження з пе- } \\
\text { ревж нням у скл ді дуб . ж- } \\
\text { ливим є т кож збільшення ос- } \\
\text { вітленості під н метом лісу (до } \\
25 \% \text { від освітлення відкритого } \\
\text { місця) для вижив ння с мосіву } \\
\text { дуб з н явності його с мосіву } \\
\text { і попереднього поновлення }\end{array}$ & $\begin{array}{l}\text { ередусім треб збері- } \\
\text { г ти молодий підріст, у } \\
\text { якого пр ктично нем } \\
\text { в д стовбурця (витягну- } \\
\text { тість, зігнутість, поля- } \\
\text { г ння). под льшого } \\
\text { відновлення в рто про- } \\
\text { водити н лежне освіт- } \\
\text { лення н дійного під- } \\
\text { росту (вік пон д } 3 \text { роки, } \\
\text { висот }-0,5-1,5 \text { м) }\end{array}$ & $\begin{array}{l}\text { ідріст доцільно формув - } \\
\text { ти густими концентрич- } \\
\text { ними куртин ми зі змен- } \\
\text { шенням висоти від центру } \\
\text { до кр їв. е з безпечить } \\
\text { високу життєзд тність і } \\
\text { стійкість куртин до дій } \\
\text { екологічних чинників. о- } \\
\text { цільно формув ти стовбу- } \\
\text { ри ялиці до 30-40- річного } \\
\text { віку у центрі густих куртин } \\
\text { для отрим ння дерев } 3 \\
\text { добре очищеним стовбу- } \\
\text { ром, збереженими від пош- } \\
\text { коджень тв рин ми і не } \\
\text { пошкодженими під ч с ру- } \\
\text { бок. огляд } 3 \text { підростом } \\
\text { треб проводити тр ди- } \\
\text { ційними способ ми рубок } \\
\text { догляду }\end{array}$ \\
\hline $\begin{array}{r}\text { ирошув ння } \\
\text { деревост нів }\end{array}$ & $\begin{array}{l}\text { p зі прочищення треб } \\
\text { зверт ти більшу ув гу н } \\
\text { формув ння скл ду т по- } \\
\text { ліпшення якості дерево- } \\
\text { ст ну, створюючи умови для } \\
\text { утворення ступінч стого н - } \\
\text { мету, потім - другого яру- } \\
\text { су. жливо не допуск ти } \\
\text { без особливої потреби виру- } \\
\text { був ння супутніх порід. ід } \\
\text { ч с проріджув ння необ- }\end{array}$ & $\begin{array}{l}\text { убк ми догляду слід форму- } \\
\text { в ти скл дні різновікові міш ні } \\
\text { н с дження дуб і ялиці у пер- } \\
\text { шому ярусі, добре вир женим } \\
\text { другим ярусом з ялиці т під- } \\
\text { ліском. деревост ні повинні } \\
\text { бути дерев всіх кл сів росту. } \\
\text { убки освітлення треб прово- } \\
\text { дити одноч сно з рубк ми го- } \\
\text { ловного користув ння. е в р- } \\
\text { то допуск ти вирубув ння су- }\end{array}$ & $\begin{array}{l}\text { йв жливішим є поєд- } \\
\text { н ння рубок формув н- } \\
\text { ня й оздоровлення і го- } \\
\text { ловного користув ння. } \\
\text { реб проводити освіт- } \\
\text { лення довкол різнові- } \\
\text { кового підросту під н - } \\
\text { метом лісу. ід ч с } \\
\text { проведення рубок пере- } \\
\text { формув ння н с джень } \\
\text { необхідно проводити }\end{array}$ & $\begin{array}{l}\text { іологічні особливості яли- } \\
\text { ці зумовлюють успішне } \\
\text { попереднє поновлення кур- } \\
\text { тин ми, тому потребують } \\
\text { проведення поет пного фор- } \\
\text { мув ння різновікових дере- } \\
\text { вост нів. оцільно прово- } \\
\text { дити комплексні рубки } \\
\text { догляду і рубки перефор- } \\
\text { мув ння. еобхідно фор- } \\
\text { мув ти скл дні н с дження }\end{array}$ \\
\hline
\end{tabular}




\begin{tabular}{|c|c|c|c|c|}
\hline 1 & 2 & 3 & 4 & 5 \\
\hline & $\begin{array}{l}\text { хідно проводити поліпшен- } \\
\text { ня скл ду т структури } \\
\text { н с джень, формуючи дру- } \\
\text { гий ярус із супутніх порід, } \\
\text { догляд ти з формою стов- } \\
\text { бурів дуб . ьому р зі } \\
\text { повнот верхнього н мету } \\
\text { повинн бути пон д } 0,6-0,8\end{array}$ & $\begin{array}{l}\text { путніх порід. p зі проріджу- } \\
\text { в ння треб поліпшув ти скл д } \\
\text { т структуру н с джень. еоб- } \\
\text { хідно догляд ти } 3 \text { формою } \\
\text { стовбур дуб т очищув ти } \\
\text { стовбури ялиці }\end{array}$ & $\begin{array}{l}\text { вирубку ч стини дерев } \\
\text { верхнього ярусу, дог- } \\
\text { ляд } 3 \text { дерев ми різного } \\
\text { віку }\end{array}$ & $\begin{array}{l}\text { 3 перев ж нням ялиці і бу- } \\
\text { к в першому ярусі, добре } \\
\text { вир женим другим ярусом } \\
\text { т підліском. дер-- } \\
\text { вост ні повинні бути де- } \\
\text { рев всіх кл сів росту і } \\
\text { розвитку. убки догляду } \\
\text { проводять одноч сно } 3 \\
\text { рубк ми головного корис- } \\
\text { тув ння }\end{array}$ \\
\hline $\begin{array}{l}\text { хист від } \\
\text { шкідників і } \\
\text { хвороб }\end{array}$ & $\begin{array}{l}\text { хист треб проводити пе- } \\
\text { рев жно біологічними мето- } \\
\text { д ми. роти листогризів } \\
\text { в рто з стосовув ти біопре- } \\
\text { п р ти. ід борошнистої } \\
\text { роси н йліпше } 3 \text { стосову- } \\
\text { в вти преп р ти колоїдної } \\
\text { сірки }\end{array}$ & $\begin{array}{l}\text { ого треб проводити лісівни- } \\
\text { чими й біологічними метод ми. } \\
\text { іологічні преп р ти н йліпше } \\
\text { з стосовув ти у вигляді водних } \\
\text { i водно-м сляних суспензій } \\
\text { проти листогризів }\end{array}$ & $\begin{array}{l}\text { ля попередження хво- } \\
\text { роб бук рубки треб } \\
\text { пл нув ти т к, щоб збе- } \\
\text { ріг лося бокове } 3- \\
\text { тінення дерев. убки } \\
\text { ліпше проводити взим- } \\
\text { ку }\end{array}$ & $\begin{array}{l}\text { еобхідно проводити пере- } \\
\text { в жно лісівничими й біо- } \\
\text { логічними метод ми }\end{array}$ \\
\hline $\begin{array}{l}\text { пособи } \\
\text { руб нь }\end{array}$ & $\begin{array}{l}\text { обровільно-вибіркові, не- } \\
\text { рівномірно-поступові н сін- } \\
\text { нєво-лісосічні і рубки пере- } \\
\text { формув ння н с джень }\end{array}$ & $\begin{array}{l}\text { рупово-вибіркові (нерівномір- } \\
\text { но групово-вибіркові), добро- } \\
\text { вільно-вибіркові, нерівномірно- } \\
\text { поступові н сіннєво-лісосічні } \\
\text { т рубки переформув ння }\end{array}$ & $\begin{array}{l}\text { рупово-вибіркові, доб- } \\
\text { ровільно-вибіркові, } \\
\text { поступові рубки, нерів- } \\
\text { номірні поступові н - } \\
\text { сіннєво-лісосічні рубки }\end{array}$ & $\begin{array}{l}\text { рупово-вибіркові, рівно- } \\
\text { мірно-поступові, групово- } \\
\text { поступові т рубки пере- } \\
\text { формув ння }\end{array}$ \\
\hline
\end{tabular}


ної т відповідних висотних місцевостей п р метри цільових деревост нів (походження, породн, віков , вертик льн і горизонт льн структур ), диференційов ні з ходи н ближеного до природного лісівництв (сприяння природному поновленню, догляд з підростом, 3 хист від шкідників і хвороб) т оптиміз цію лісокористув ння (рекомендов ні способи рубок).

1. нучин . . есн я т кс ция : 5-е изд./ . . нучин. - . . есн я пром-сть, 1982. -552 с.

2. уш . . кологические и технологические основы рубок уход / . . уш, . . евинь. иг : ин тне, 1984. - $172 \mathrm{c}$.

3. оробъев. . . етодик лесотипологических исследов ний / . . оробъев. - иев : рож й, 1969. - 388 с.

4. еренчук .. . ндш фти / . . еренчук // рирод кр їнських рп т. - ьвів : ид-во ьвів. ун-ту, 1968. - .208-238.

5. олубець . . еобот нічне р йонув ння кр їнських рп т - основ р ціон льного природокористув ння / . . олубець // $\mathrm{p}$ ці , 2003. - .12. кол. зб. кологічні проблеми рп тського регіону. - .283-293.

6. олубець . . онцепту льні з с ди ст лого розвитку гірського регіону / . . олубець, . . н тів, . . озловський. - ьвів : оллі, 2007. -288 с.

7. $y x$. . ндш фтн к рт ьвівської обл сті м сшт бу $1: 200000$ / . . у ух // існ. ьвів. ун-ту. ер. геогр. $-2003 .-$ ип. 29. - . 1. - .58-65.

8. ближене до природи лісівництво в кр їнських рп т х / . ернявський, . віттер, . . ов лишин [т ін.]; з ред. . . ернявського. - ьвів : “ ір мід ”, 2006. -88 с.

9. тойко . . колого-економічні принципи оптиміз ції тр нсформов них лісів кр їни н з с д х системи н ближеного до природного лісівництв / . . тойко // ук. вісн. ц. лісотехн. ун-ту кр їни. $-2005 .-$ ип. 15.6. - .78-86.

10. тойко . . убові ліси кр їнських рп т: екологічні особливості, відтворення, охорон / . тойко. - ьвів, 2009. -220 с.

11. еліш . . нтропогенн тр нсформ ція в ліс х ерхньодністровських ескидів і шляхи їі оптиміз ції / . . еліш // існ. ьвів. ун-ту. ер. геогр. - 2009. - ип. 37. - . 187-199.

12. еліш . . колого-геогр фічні основи комплексного використ ння лісових ресурсів ерхньодністровських ескидів : втореф. дис. н здобуття н ук. ступеня к нд. геогр. н ук : спец. 11.00.11 “ онструктивн геогр фія і р ціон льне використ ння природних ресурсів” / . . еліш. - ьвів, 2011. - 20 с.

13. ретяк . . т н лісів т екологічні проблеми лісового господ рств ьвівщини / . . ретяк, . . риницький, . . ейнек // р ці .-2001. - .7. кол. збірник.- .43-51

14. ткин . . пок з телях лесных биогеоценозов / . . ткин // юлл. оск. об-в испыт т. природы. тд. биологии. - 1975. . 80 (2). - . .95-107.

15. ернявський . . б ближене до природи ведення лісового господ рств в кр їні / . . ернявський // ісовий і мисливський журн. - 2008. - № 1. - . 14-17.

16. ернявський . . убки переформув ння деревост нів / . . ернявський // укові основи підвищення продуктивності т біологічної стійкості лісових т урб нізов них екосистем. - ьвів, 2005. - . 85-88.

17. ернявський . . ближене до природи лісівництво як стр тегія суч сного ведення лісового господ рств / . . ернявський // сновні причини знеліснення т дегр д ції лісів в кр їні : м тері ли міжн р. н ук.-пр кт. конф., 20-22 вер. 2009 р. - ьвів, 2010. - . 22-30.

18. Fregner M., Wasser B., Schwitter R. Nachhaltigkeit und Erfolgskontrole im Schutzwald. Wegleitung fuer Pflegemassnahmen in Waeldern mit Schutzfunktion, Vollzug Umwelt. - Bern : Bundesamt fuer Umwelt, Wald und Landschaft. 2005. - 564 S.

m ття: н дійшл до редколегії 09.11.2011 прийнят до друку 20.12.2011 


\title{
GEOGRAPHIC ASPECTS OF OPTIMIZATION FORESTS OF UPPER DNIESTER BESKIDS ON CLOSE TO NATURE FORESTRY
}

\section{Chernyavskyy ${ }^{1}$, P. Telish $^{2}$}

${ }^{1}$ Ukrainian National Forestry University, Kobyljanska St., 1, Lviv, U -79005, Ukraine

${ }^{2}$ Ivan Franko National University of Lviv, . Doroshenko St., 41, UA - 79000 Lviv, Ukraine

Proved system of measures aimed at the reconstruction of the derivatives forest Upper Dniester Beskydy. Within the high-altitude forest zones and high-altitude landscape areas the tree stands options, targeted measures to approximate the natural forest and the recommended methods of felling have been proposed.

Key words: Upper Dniester Beskids, high-altitude forest zones, forest harvesting methods, the target stands.

\author{
• ернявский ${ }^{1}$, . елиш ${ }^{2}$ \\ 1 ион льный лесотехнический университет кр ины, \\ ул. . обылянской, 1, г. ьвов, 79005, кр ин \\ 2 ввовский н ицон льный университет имени вн н \\ ул. . орошенко, 41, г. ьвов, 79000, кр ин
}

боснов но систему мероприятий, н пр вленных н реконструкцию производных лесов в ерхнеднестровских ескид х. предел х высотных р стительных поясов и высотных л ндш фтных местностей предложено п р метры целевых древостоев, лесоводственные системы, близкие к р звитию природных лесов, и рекомендуемые способы рубок.

лючевые слов : ерхнеднестровские ескиды, высотные р стительные пояс, лес , способы рубок, целевые древостои. 